\title{
PENINGKATAN PRESTASI BELAJAR TEKNIK LISTRIK DASAR OTOMOTIF MELALUI METODE “THINK-PAIR-SHARE” PADA SISWA SMK NEGERI 1 BAURENO KABUPATEN BOJONEGORO
}

\author{
Achmad Niam Shofi \\ niam_shofi@rocketmail.com \\ SMK Negeri I Baureno Bojonegoro
}

\begin{abstract}
Abstrak
Upaya peningkatan mutu pendidikan dan pengajaran dibutuhkan pembelajaran kooperatif dengan pendekatan struktural "Think-pair-share" yang ditetapkan secara eksplisit dengan memberi siswa waktu lebih banyak berpikir, menjawab, dan membantu satu sama lain. Tujuan penelitian adalah mengetahui pengaruh penggunaan model Cooperative Learning dengan pendekatan struktural "Think-Pair-Share" terhadap peningkatan ketuntasan belajar mata pelajaran Teknik Listrik Dasar Otomotif (TKDO) pada Kompetensi Dasar (KD) memahami dan membaca alat ukur listrik sesuai SOP siswa Kelas X-TKR2 SMKN 1 Baureno Kabupaten Bojonegoro. Pendekatan yang digunakan dalam penelitian ini adalah pendekatan kuantitatif, dengan jenis penelitian tindakan. Hasil penelitian menunjukkan perubahan yang signifikan pada hasil belajar (prestasi) dari Siklus I sampai dengan Siklus II yaitu dari siklus I : 71,88 (ketuntasan 56,25\%) meningkat menjadi 81,41 (ketuntasan 93,75\%), maka dapat disimpulkan ada peningkatan ketuntasan belajar mata pelajaran TKDO pada KD memahami dan membaca alat ukur listrik sesuai SOP siswa Kelas X-TKR2 SMKN 1 Baureno Kabupaten Bojonegoro.
\end{abstract}

Kata kunci: Prestasi belajar, think pair share

\section{PENDAHULUAN}

Pendidikan di Indonesia dewasa ini telah mengalami perbaikan dari tahun ke tahun, mulai dari perbaikan kurikulum hingga perbaikan standar kelulusan siswa. Selain itu, perkembangan teknologi informasi, banyaknya pengangguran serta beratnya persaingan dalam mencari kerja adanya penyetaraan pendidikan baik dalam konteks nasional maupun internasional merupakan beberapa faktor dan tuntutan agar pendidikan harus lebih baik.

Lembaga pendidikan pada saat ini terutama pendidikan menengah Kejuruan ditantang oleh perkembangan informasi serta teknologi yang pesat agar mampu bersaing di dunia industri. Sekolah Menengah Kejuruan (SMK) Negeri 1 Baureno Kabupaten Bojonegoro merupakan Sekolah Kejuruan yang membuka program keahlian Tata Busana, Teknik Listrik Dasar Otomotif, dan lainlain. Berdasarkan pengamatan dan pengalaman peneliti di SMK Negeri 1 Baureno Kabupaten Bojonegoro, khususnya di jurusan Teknik Listrik Dasar Otomotif motivasi siswa dalam mengikuti proses pembelajaran masih sangat rendah.

Banyak faktor yang dapat mempengaruhi keberhasilan implementasi kurikulum, beberapa faktor tersebut diantaranya manajemen lembaga pendidikan, peran guru, keaktifan siswa, proses belajar pengajar, sarana dan prasarana, penggunaan model dan metode mengajar dan lain-lain.

Bila kita meninjau aktifitas kelas, maka guru adalah ujung tombak proses belajar mengajar. Seorang guru diharapkan memiliki kompetensi yang cukup sebagai pengelola pembelajaran, mampu menciptakan susasana dan lingkungan belajar yang efektif. Selain itu diharapkan terjadi suasana dan lingkungan belajar yang dapat meningkatkan aktifitas, kreativitas, dan keaktifan siswa sebagai subjek belajar. Jangan sampai siswa pasif dan miskin kreativitas guru lebih besar dibanding siswa. 
p-ISSN: 2503-1228; e-ISSN: 2621-4172

Artinya dengan menggunakan strategi pembelajaran yang benar akan mengarahkan siswa pada ketercapaian tujuan pendidikan yang dirumuskan. Sebagai contoh adalah mata pelajaran Teknik Listrik Dasar Otomotif untuk siswa Kelas X-TKR2 SMK Negeri 1 Baureno Kabupaten Bojonegoro Semester Ganjil Tahun Pelajaran 2018/2019. Ada beberapa temuan yang diperoleh oleh peneliti menunjukkan kurangnya partisipasi siswa dalam mengikuti pembelajaran. Guru cenderung aktif sedangkan siswanya pasif. Hal ini disebabkan guru lebih senang menggunakan strategi pembelajaran konvensional seperti menerangkan materi sehingga siswa bosan. Kondisi ini menyebabkan prestasi belajar siswa sangat rendah.

Berdasarkan pernyataan diatas, maka semestinya guru dapat memilih dan menggunakan model atau metoda pembelajaran yang lebih relevan. Pertanyaan yang timbul adalah model pembelajaran bagaimanakah yang dapat meningkatkan aktivitas, kreativitas, dan keaktivan anak dalam proses belajar mengajar. Metode tersebut harus mampu membuat komunikasi berlangsung dua arah, meningkatkan penguaasaan materi dan meningkatkan prestasi belajar siswa.

\section{Contextual Teaching and Learning}

Contextual Teaching and Learning atau pembelajaran kontekstual adalah konsep belajar dimana guru menghadirkan dunia nyata kedalam kelas dan mendorong siswa membuat hubungan antara pengetahuan yang dimilikinya dengan penerapan dalam kehidupan sehari-hari. Sementara siswa memperoleh pengetahuan dan keterampilan dari konteks, yang terbatas, sedikit demi sedikit dari proses mengkonstruksi sendiri sampai pemecahan masalah kehidupan. Nurhadi (2004: 13)

\section{Cooperative Learning/ Pembelajaran Kooperatif}

Cooperative learning atau pembelajaran kooperatif adalah pembelajaran yang secara sadar dan sistematis mengembangkan interaksi yang saling asah, saling asih antara sesama siswa sebagai latihan hidup di dalam masyarakat nyata.

Menurut Holubec (2001) dalam Nurhadi, Burhan Yasin, Agus Gerrad Senduk (2004: 61) pengajaran kooperatif memerlukan pendekatan pengajaran melalui penggunaan kelompok kecil siswa untuk bekerja sama dalam memaksimalkan kondisi belajar dalam mencapai tujuan belajar.

Dari penjelasan di atas, terkandung arti bahwa dalam pembelajaran kooperatif secara sadar menciptakan interaksi yang saling mencerdaskan sehingga sumber belajar bagi siswa bukan hanya guru dan buku ajar tetapi juga sesama siswa.

\section{Active Learning/ Pembelajaran Aktif}

Belajar aktif merupakan sebuah kesatuan sumber kumpulan strategistrategi pembelajaran yang komprehensif. Belajar aktif meliputi berbagai cara untuk membuat cara peserta didik aktif sejak awal melalui aktifitas-aktifitas yang membangun kerja kelompok dan dalam waktu singkat membuat mereka berpikir tentang materi pelajaran. Belajar aktif mengajarkan informasi konsep-konsep dan keterampilan-keterampilan teknis dan nonteknis.

\section{Pendekatan Struktural Think-Pair-Share}

Strategi ini tumbuh dari penelitian pembelajaran kooperatif dan waktu tunggu. Pendekatan khusus yang diuraikan disini mula-mula dikembangkan oleh Frank Lyman dkk dari univrsitas Meryland pada tahun 1985. Ini merupakan cara yang efektif untuk mengubah pola diskursus di dalam kelas. Strategi ini menantang asumsi bahwa seluruh resitasi dan diskusi perlu dilakukan di dalam seting seluruh kelompok. Think-Pair-Share memiliki 
prosedur yang ditetapkan secara eksplisit untuk memberi siswa waktu lebih banyak untuk berpikir, menajawab, dan saling membantu satu sama lain. Andaikan guru baru saja menyelesaikan suatu penyajian singkat atau siswa telah membaca suatu tugas. Sekarang guru menginginkan siswa memikirkan secara lebih mendalam tentang apa yang telah dijelaskan atau dialami. Ia memilih untuk menggunakan strategi Think-Pair-Share sebagai gantinya tanya jawab seluruh kelas. Ia menerapkan langkah-langkah sebagai berikut ini:

\section{Tahap 1}

Thinking (berpikir). Guru mengajukan pertanyaan atau isu yang berhubungan dengan pelajaran, kemudian siswa diminta untuk memikirkan pertanyaan atau isu tersebut secara mandiri untuk beberapa saat.

\section{METODE}

Penelitian ini merupakan penelitian tindakan kelas yang dilakukan untuk meningkatkan prestasi belajar Teknik Listrik Dasar Otomotif pada kompetensi dasar memahami dan membaca alat ukur listrik sesuai SOP dan meningkatkan kerjasama siswa dalam pembelajaran Teknik Listrik Dasar Otomotif di kelas. Proses pelaksanaan tindakan kelas melalui empat tahap (dalam 2 siklus) mulai dari (1) perencanaan (planning), (2) tindakan (acting), (3) pengamatan (observing) dan (4) refleksi (reflecting). (Depdikbud, 2005: 4)

Penelitian dilaksanakan di SMK

Negeri 1 Baureno Kabupaten Bojonegoro Tahun Pelajaran 2018/2019 semester I, dengan mengambil objek penelitian siswa Kelas X-TKR2 dengan jumlah siswa 32 siswa. Penelitian tindakan kelas ini mengambil mata pelajaran Teknik Listrik Dasar Otomotif pada kompetensi dasar memahami dan membaca alat ukur listrik sesuai SOP. Siswa SMK Negeri 1 Baureno Kabupaten Bojonegoro kurang lebih 50\% siswa berasal dari keluarga menengah.

\section{Tahap 2}

Pairing. Guru meminta siswa berpasangan dengan siswa yang lain untuk mendiskusikan apa yang telah dipikirkannya pada tahap pertama. Interaksi pada tahap ini diharapkan dapat berbagi jawaban jika suatu persoalan khusus telah didentifikasi.. Biasanya guru memberi waktu 4-5 menit untuk berpasangan.

Tahap 3

Sharing. Pada tahap akhir, guru meminta kepada pasangan untuk berbagi dengan seluruh kelas tentang apa yang telah dibicarakan. Ini efektif dilakukan dengan cara bergiliran pasangan demi pasangan dan dilanjutkan sampai sekitar seperempat pasangan telah mendapatkan kesempatan unruk melaporkan.

Dari kondisi inilah menyebabkan perhatian orang tua terhadap anak sangatlah kurang. Kurangnya perhatian orang tua ini juga menyebabkan kurangnya minat belajar pada siswa.

Untuk penulisan data yang valid maka disiapkan lembar observasi untuk memperoleh data secara akurat. Tes hasil belajar untuk memperoleh tingkat keberhasilan metode pembelajaran. Dimana keberhasilan metode ini meliputi:

a. Keaktifan siswa dalam mengikuti kegiatan belajar mengajar.

b. Peningkatan hasil belajar, khususnya mata pelajaran Teknik Listrik Dasar Otomotif pada kompetensi dasar memahami dan membaca alat ukur listrik sesuai SOP.

c. Peningkatan minat siswa terhadap mata pelajaran Teknik Listrik Dasar Otomotif khususnya kompetensi dasar memahami dan membaca alat ukur listrik sesuai SOP.

Penelitian ini menggunakan dua siklus dengan langkah sebagai berikut: 


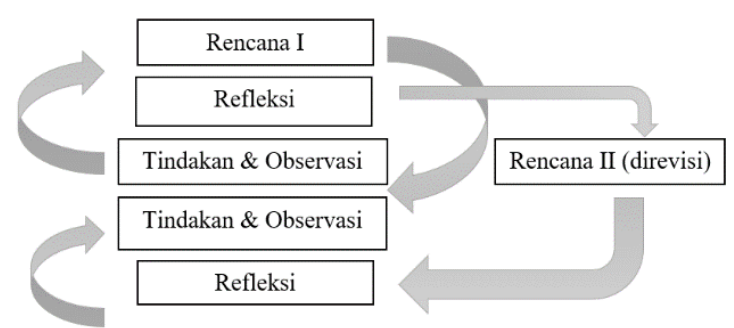

Gambar 1. Gambar Siklus Penelitian Tindakan Kelas B

(Sumber: Kemmis dan Taggart dalam Hartatiek, 2002: 5)

Analisis data dalam penelitian tindakan kelas ini masuk pada tahap refleksi, peneliti dan praktisi (guru) mendiskusikan hasil pengamatan tindakan yang telah dilaksanakan. Hal-hal yang dilakukan adalah

d. Analisis tentang tindakan yang dilakukan.

e. Mengulas dan menjelaskan perbedaan rencana dengan pelaksanaan tindakan yang telah dilaksanakan.

f. Melakukan intervensi, pemaknaan dan penyimpulan data yang telah diperoleh, serta melihat hubungan dengan teori dan rencana yang telah ditetapkan.

Data yang diperoleh dalam penelitian ini adalah data kuantitatif yang berasal dari nilai kemampuan memahami,

\section{PEMBAHASAN}

\section{Siklus I}

\section{Perencanaan (planning)}

Pada tahap proses rencana tindakan ini, mula-mula guru mengidentifikasikan konsep-konsep Teknik Listrik Dasar Otomotif pada kompetensi dasar memahami dan membaca alat ukur listrik sesuai SOP yang sukar dipahami siswa.

Berdasarkan masalah tersebut, sebagai acuan implementasi tindakan yang dipilih pada konsep tersebut dipelajari dan diidentifikasi, maka guru menyusun rencana pembelajaran. Rencana pembelajaran ini memuat:

a. Guru menyampaikan inti materi dan kompetensi yang ingin dicapai. nilai afektif siswa dan hasil post test dilihat dari pencapaian standar ketuntasan belajar minimal (SKM). Analisis dan refleksi terhadap data yang diperoleh dipaparkan dalam bentuk deskripsi. Agar mendapat gambar yang jelas, maka teknik statistik yang digunakan dengan rumus mean (ratarata), yaitu: $M=\frac{\sum x}{N}$

Keterangan : $\mathrm{M}=$ Nilai rata-rata

$$
\begin{aligned}
& \sum \mathrm{x}=\text { Jumlah nilai siswa } \\
& \mathrm{N}
\end{aligned}
$$

Sedangkan untuk mengetahui prosentase ketuntasan belajar dengan rumus:

Prosentase ketuntasan $=\frac{\text { Jumlah siswa tuntas }}{\text { Jumlah seluruh kelas }} x 100$

b. Siswa diminta berpikir tentang materi/ permasalahan yang disampaikan guru.

c. Siswa diminta berpasangan dengan teman sebelahnya (kelompok 2 orang) dan mengutarakan hasil pemikiran masing-masing.

d. Guru memimpin pleno kecil diskusi, tiap kelompok mengemukakan hasil diskusinya.

e. Berawal dari kegiatan tersebut mengarahkan pembicaraan pada pokok permasalahan dan menambah materi yang belum diungkapkan para siswa.

f. Guru memberi kesimpulan.

g. Penutup

h. Penelitian ini dilaksanakan di Kelas X-TKR2 SMK Negeri 1 Baureno Kabupaten Bojonegoro 
p-ISSN: 2503-1228; e-ISSN: 2621-4172

Tahun pelajaran 2018/2019 semester 1 .

2. Pelaksanaan (acting)

Pelaksanaan penelitian tindakan

kelas (PTK) ini dilakukan pada saat

kegiatan belajar mengajar Teknik

Listrik Dasar Otomotif di sekolah. Hasil

pelaksanaan pada siklus I sebagai

berikut dapat diketahui:

$$
\text { Rata }- \text { rata }=\frac{2300}{32}=71,88
$$

Sedangkan prosentase ketuntasan belajar:

Ketuntasan belajar $=\frac{18}{32} \times 100 \%=56,25 \%$

Hasil angket tanggapan siswa tentang pembelajaran Teknik Listrik Dasar Otomotif dengan menggunakan metode Think-Pair-Share dapat ditunjukkan dengan tabel sebagai berikut:

Tabel 1. Angket Tanggapan Siswa Siklus I

\begin{tabular}{|c|c|c|c|c|}
\hline \multirow{2}{*}{ No } & \multirow{2}{*}{ Pertanyaan } & \multicolumn{3}{|c|}{ Jawaban (\%) } \\
\hline & & Ya & Sama Saja & Tidak \\
\hline 1 & $\begin{array}{l}\text { Apakah kamu senang pembelajaran Teknik Listrik } \\
\text { Dasar Otomotif dengan menggunakan metode } \\
\text { TPS? }\end{array}$ & 45.83 & 25.00 & 29.17 \\
\hline 2 & $\begin{array}{l}\text { Apakah pembelajaran Teknik Listrik Dasar } \\
\text { Otomotif dengan menggunakan metode TPS kamu } \\
\text { lebih mudah memahami materi? }\end{array}$ & 58.33 & 12.50 & 29.17 \\
\hline & $\begin{array}{l}\text { Apakah pembelajaran Teknik Listrik Dasar } \\
\text { Otomotif dengan menggunakan metode TPS kamu }\end{array}$ & & & \\
\hline 3 & $\begin{array}{l}\text { lebih mudah mengetahui contoh penerapan Teknik } \\
\text { Listrik Dasar Otomotif dalam kehidupan sehari- } \\
\text { hari? }\end{array}$ & 70.83 & 25.00 & 4.17 \\
\hline 4 & $\begin{array}{l}\text { Apakah pembelajaran Teknik Listrik Dasar } \\
\text { Otomotif dengan metode TPS kamu lebih rileks? }\end{array}$ & 54.17 & 20.83 & 25.00 \\
\hline 5 & $\begin{array}{l}\text { Apakah kamu berdiskusi dengan temanmu jika } \\
\text { mengalami kesulitan? }\end{array}$ & 50.00 & 20.83 & 29.17 \\
\hline 6 & $\begin{array}{l}\text { Apakah kamu mengerjakan tugas yang diberikan } \\
\text { gurumu? }\end{array}$ & 75.00 & 20.83 & 4.17 \\
\hline 7 & $\begin{array}{l}\text { Apakah kamu merasa jenuh jika pembelajaran } \\
\text { Teknik Listrik Dasar Otomotif menggunakan } \\
\text { metode TPS dilaksanakan terus menerus? }\end{array}$ & 16.67 & 20.83 & 62.50 \\
\hline
\end{tabular}

\section{Observasi (observing)}

Teknik observasi dilakukan

secara terus menerus dalam proses pembelajaran maupun pada hasil belajar. Evaluasi dilakukan terhadap dampak dari pemberian metode "Think-Pair-Share" selama proses belajar mengajar terhadap hasil belajar dan peningkatan minat siswa.

Dari hasil evaluasi diketahui keefektifan metode "Think-Pair-Share" yang telah disusun, untuk memperbaiki akan diberikan pada siklus II. Selain itu hasil observasi juga memberikan petunjuk apakah pengajaran remidi perlu dilakukan pada akhir siklus II.

4. Refleksi (reflecting)

Adapun hasil penelitian pada siklus I adalah sebagai berikut: Pada siklus pertama proses kegiatan belajar mengajar tidak seperti yang diharapkan, hal ini mungkin disebabkan dari:

a. Penyebaran anak-anak pandai tidak merata dalam setiap kelompok. Hal ini disebabkan pembagian kelompok diatur hanya sebatas teman sebangku.

b. Tidak ada sarana dan prasarana penunjang lain seperti buku paket penunjang yang sesuai sehingga kesiapan siswa kurang baik.

c. Tidak cukup waktu bagi siswa untuk memahami modul atau diktat karena dibagikan secara mendadak.

Dengan asumsi kurang efektifan

dalam proses belajar mengajar yang meliputi 4 faktor tersbut, maka hal ini diperbaiki pada siklus II. 


\section{Siklus Kedua}

1. Perencanaan (planning)

Pada tahap proses rencana tindakan ini, mula-mula guru mengidentifikasikan konsep-konsep Teknik Listrik Dasar Otomotif pada kompetensi dasar memahami dan membaca alat ukur listrik sesuai SOP yang sukar dipahami siswa.

Berdasarkan masalah tersebut, sebagai acuan implementasi tindakan yang dipilih pada konsep tersebut dipelajari dan diidentifikasi, maka guru menyusun rencana pembelajaran. Rencana pembelajaran ini memuat:

a. Guru menyampaikan inti materi dan kompetensi yang ingin dicapai.

b. Siswa diminta berpikir tentang materi/ permasalahan yang disampaikan guru.

c. Guru membagi beberapa kelompok secara acak (kelompok 2 orang) dan mengutarakan hasil pemikiran masing-masing.

d. Guru memimpin pleno kecil diskusi, tiap kelompok mengemukakan hasil diskusinya.

e. Berawal dari kegiatan tersebut mengarahkan pembicaraan pada pokok permasalahan dan menambah materi yang belum diungkapkan para siswa.

f. Guru memberi kesimpulan.

g. Penutup

2. Pelaksanaan (acting)

Tindakan utama pada siklus II adalah pemberian modul/ diktat kompetensi dasar memahami dan membaca alat ukur listrik sesuai SOP untuk meningkatkan kemampuan awal siswa dan merevisi kesalahan-kesalahan konsep pada siklus I, yang mungkin menyebabkan hambatan-hambatan bagi pengembangan pemahaman siswa atas konsep-konsep yang akan dipelajari.

Pelaksanaan PTK ini dilakukan pada saat kegiatan belajar mengajar di sekolah.hasil penilaian pada siklus II sebagai berikut:

$$
\text { Rata }- \text { rata }=\frac{2605}{32}=81,41
$$

Sedangkan prosentase ketuntasan belajar

Ketuntasan belajar $=\frac{30}{32} \times 100 \%=93,75 \%$

Hasil angket tanggapan siswa tentang pembelajaran Teknik Listrik Dasar Otomotif dengan menggunakan metode "Think-Pair-Share" dapat ditunjukkan dengan tabel sebagai berikut:

Tabel 2. Angket Tanggapan Siswa Siklus II

\begin{tabular}{|c|c|c|c|c|}
\hline \multirow{2}{*}{ No } & \multirow{2}{*}{ Pertanyaan } & \multicolumn{3}{|c|}{ Jawaban (\%) } \\
\hline & & Ya & Sama Saja & Tidak \\
\hline 1 & $\begin{array}{l}\text { Apakah kamu senang pembelajaran Teknik Listrik Dasar } \\
\text { Otomotif dengan menggunakan metode TPS? }\end{array}$ & 79.17 & 20.83 & 0.00 \\
\hline 2 & $\begin{array}{l}\text { Apakah pembelajaran Teknik Listrik Dasar Otomotif dengan } \\
\text { menggunakan metode TPS kamu lebih mudah memahami } \\
\text { materi? }\end{array}$ & 75.00 & 20.83 & 4.17 \\
\hline 3 & $\begin{array}{l}\text { Apakah pembelajaran Teknik Listrik Dasar Otomotif dengan } \\
\text { menggunakan metode TPS kamu lebih mudah mengetahui } \\
\text { contoh penerapan Teknik Listrik Dasar Otomotif dalam } \\
\text { kehidupan sehari-hari? }\end{array}$ & 70.83 & 25.00 & 4.17 \\
\hline 4 & $\begin{array}{l}\text { Apakah pembelajaran Teknik Listrik Dasar Otomotif dengan } \\
\text { metode TPS kamu lebih rileks? }\end{array}$ & 87.50 & 12.50 & 0.00 \\
\hline 5 & $\begin{array}{l}\text { Apakah kamu berdiskusi dengan temanmu jika mengalami } \\
\text { kesulitan? }\end{array}$ & 75.00 & 12.50 & 12.50 \\
\hline 6 & $\begin{array}{l}\text { Apakah kamu mengerjakan tugas yang diberikan gurumu? } \\
\text { Apakah kamu merasa jenuh jika pembelajaran Teknik Listrik }\end{array}$ & 83.33 & 12.50 & 4.17 \\
\hline 7 & $\begin{array}{l}\text { Dasar Otomotif menggunakan metode TPS dilaksanakan terus } \\
\text { menerus? }\end{array}$ & 0.00 & 4.17 & 95.83 \\
\hline
\end{tabular}


3. Observasi (observing)

Teknik observasi dilakukan secara kontinue atau terus menerus dalam proses pembelajaran maupun pada hasil belajar. Evaluasi dilakukan terhadap dampak dari pemberian metode "Think-Pair-Share" selama proses belajar mengajar terhadap hasil belajar dan peningkatan minat siswa.

a. Teknik observasi dilakukan secara terus menerus dalam proses pembelajaran maupun pada hasil belajar.

b. Keaktifan anggota kelompok dalam menyelesaikan tugas.

c. Peningkatan kemampuan pada setiap kelompok.

d. Peningkatan minat siswa terhadap mata pelajaran Teknik Listrik Dasar Otomotif khususnya kompetensi dasar memahami dan membaca alat ukur listrik sesuai SOP.

e. Refleksi (reflecting)

Pada siklus II proses kegiatan belajar mengajar sudah lebih baik dari siklus I hal ini disebabkan kelemahan- kelemahan pada siklus I sudah diperbaiki antara lain:

a. Penyebaran anak disesuaikan dengan kemampuan anak dalam kelas tersebut.

b. Kelompok siswa diperbaiki dengan pembentukan secara acak yang sebelumnya pada siklus I hanya sebatas teman sebangku.

c. Sarana media pembelajaran dilengkapi.

d. Modul atau materi pembelajaran diberikan lebih awal sehingga siswa lebih siap dalam proses belajar mengajar.

Berdasarkan hasil penilaian dan pengamatan siswa guru menunjukkan bahwa dengan menggunakan "Think-PairShare" dapat membantu siswa dalam meningkatkan memahami pelajaran Teknik Listrik Dasar Otomotif pada kompetensi dasar memahami dan membaca alat ukur listrik sesuai SOP. Data perbandingan nilai rata-rata setiap siklus.

Tabel 3. Perbandingan Rata-rata setiap Sklus

\begin{tabular}{|c|c|c|}
\hline Kelas & Siklus I & Siklus II \\
\hline Kelas X-TKR2 & 72.88 & 81.41 \\
\hline
\end{tabular}

Tabel 4. Perbandingan Ketuntasan Belajar

\begin{tabular}{|c|c|c|}
\hline Kelas & Siklus I & Siklus II \\
\hline Kelas X-TKR2 & $56,25 \%$ & $93,75 \%$ \\
\hline
\end{tabular}

Dari hasil pelaksanaan dan pengamatan siswa dan guru cenderung lebih baik setiap siklus, maka dapat disimpulkan bahwa: Ada Peningkatan Prestasi Belajar Teknik Listrik Dasar Otomotif Melalui Metode Think-Pair-Share.

\section{KESIMPULAN}

Dari hasil pengamatan dan analisis hasil kegiatan siswa serta guru, selama PTK diperoleh hal-hal sebagai berikut:

a. Terjadi perubahan tingkah laku pada sebagian besar siswa kearah yang lebih baik, diantaranya adalah minat belajar, keingintahuan, motivasi, keberanian melakukan tindakan (psikomotorik), keberanian menyampaikan pendapat (afektif) baik secara individu maupun kelompok.

b. Terjadi perubahan yang signifikan pada hasil belajar (prestasi) dari Siklus I sampai dengan Siklus II yaitu dari siklus I : 71,88 (ketuntasan $56,25 \%$ ) meningkat menjadi 81,41 (ketuntasan 93,75\%) pada siklus II.

c. Terjadi perubahan kinerja guru menjadi lebih baik, diantaranya adalah kreatifitas menyusun bahan 
ajar, peranan guru dan inovatif dalam mengelola kegiatan belajar mengajar.

Berdasarkan hal-hal Cooperative

Learning dengan pendekatan struktural

“Think-Pair-Share” dapat meningkatkan

\section{DAFTAR PUSTAKA}

Departemen Pendidikan dan Kebudayaan

Direktorat Jenderal Pendidikan Dasar dan Menengah Direktorat Pendidikan Menengah Umum. 1999. Bahan Pelatihan Penelitian Tindakan (Action Research); Jakarta. Depdikbud.

Departemen Pendidikan Naional Direktorat Jenderal Pendidikan Dasar dan Menengah Direktorat Pendidikan Menengah Umum. 2000. Panduan Kurikulum Metode Alternatif Belajar/ Mengajar. Jakarta. Depdikbud.

Dinas Pendidikan dan Kebudayaan Satker Pembinaan Pendidikan Menengah Umum (2005/2006). Buku Materi Workshop Penelitian Tindakan kelas (PTK). Jawa Timur.

Departemen Pendidikan Nasional Kurikulum 2004. Pedoman Khusus Pengembangan Silabus dan Penilaian. minat belajar dan prestasi siswa baik aspek kognitif belajar mata pelajaran Teknik Listrik Dasar Otomotif pada kompetensi dasar memahami dan membaca alat ukur listrik

Departemen Pendidikan Nasional Kurikulum 2004. Standar Kompetensi Mata Pelajaran IPS.

Melvin L. Silberman, 1996. Active Learning: 101 Strategies to Teach Any Subject. Boston: Allyn Bacon.

Nurhadi dkk, (II Rev.2004) Pembelajaran Kontekstual (Contextual Teaching and Learning/ CTL) dan Penerapannya dalam KBK; Malang; Penerbit Universitas Negeri Malang.

Rachiati Wiriatmadja, 2005. Metode Penelitian Tindakan Kelas. Bandung: PT. Remaja Rosdakarya.

Suharsimi Arikunto, Suhardjono, Supardi, 2006. Penelitian Tindakan Kelas. Jakarta: PT. Bumi Aksara.

Wawang Hutawarman, 2004. Model-Model Pembelajaran Kooperatif.

Workshop PTK, 2005. Pedoman Khusus Pengembangan Instrumen dan Penilaian Ranah Afektif, Dinas P dan $\mathrm{K}$. 